\title{
THE EFFECT OF ETHNOMATHEMATICS-BASED SAVI (SOMATIC, AUDITORY, VISUALIZATION, INTELECTUALLY) APPROACH ON MATHEMATICAL COMMUNICATION SKILL ON GEOMETRY IN ELEMENTARY SCHOOL
}

\author{
Laely Farokhah ${ }^{1 *}$, Andika Arisetyawan ${ }^{2}$, Al Jupri ${ }^{3}$ \\ ${ }^{1}$ Universitas Pendidikan Indonesia, Indonesia, laely_farokhah@student.upi.edu \\ ${ }^{2}$ Universitas Pendidikan Indonesia, Indonesia, andikaarisetyawan@upi.edu \\ 3Universitas Pendidikan Indonesia, Indonesia, aljupri@upi.edu \\ ${ }^{*}$ Corresponding author
}

\begin{abstract}
The mathematics learning process in elementary schools is still focused on the more active teachers in the classroom than students. Students are not much given the opportunity to gain direct experience in the learning process so that it causes low understanding of mathematical concepts and mathematical communication skill of students. The aim of this research are to obtain a description of the effect of ethnomathematics-based SAVI (Somatic, Auditory, Visualization, Intellectually) approach on mathematical communication skill of students in geometry in $5^{\text {th }}$ grade one of elementary school in Serang, Indonesia and to gain an overview of the results of mathematical communication skill of students using ethnomathematicsbased SAVI approach better than the use of conventional learning. The research was quantitative research and employed quasi experimental research which is nonequivalent control group design. This research was located at one of elementary school in Serang, Indonesia. The subjects of this research were 38 students of class A as an experimental class and 38 students class B as a control class. The data were collected through test which is mathematical communication skill test and interviews and analyzed by using data processing SPSS 21 version programs. The result showed that the average of pre-test of mathematical communication skill in experimental class is 40,92 and the control class is 34,74 . After given different treatment and the final mathematical communication skill test, the average value is 72,11 in experimental class and 60,53 for the control class. The mean value of gain is 0,53 in experimental class including the medium category. So based on these results, it can be concluded that the ethnomathematics-based SAVI approach affects to mathematical communication skill of students.
\end{abstract}

Keywords: Ethnomathematics-based SAVI, Mathematical Communication, Geometry, Elementary School

\section{INTRODUCTION}

Mathematics is one of subjects that can prepare the students to face the $21^{\text {st }}$ century challenges. Learning and innovation skills to prepare students to face complex life and work environments in today's world consist of creativity and innovation, critical thinking and problem solving, communication, and collaboration (Partnership for $21^{\text {st }}$ century learning, 2007). In addition, mathematics learning process in elementary school 
is an important phase for children in understanding the concept of mathematics. In this elementary education level, chidren will build the foundations of mathematical concepts. The teacher should be able to design mathematics learning process based on the characteristic of elementary school students. According to Ollerton (2010), teaching is more than just finding ways to transfer the knowledge, teaching is about organizing learning so students can be confident to try the new ideas, find the relationships and the opportunities to do the creative and analytical action, develop the generality, and take the initiative.

The mathematical communication skill is very important to the students. The importance of communication is stated in the Kurikulum 2013, as curriculum of teaching and learning used in Indonesia right now, that mathematics education in schools is expected to contribute in supporting the achievement of the competency of elementary and secondary education graduates through learning experience, one of them is to solve problems and communicate ideas through symbols, tables, diagrams, or other media to clarify the situation or problem (Kemendikbud, 2016). Moreover, Through this mathematical communication skills students can develop an understanding of mathematics when using correct mathematical language to write about mathematics, clarify ideas and learn to make the argument and represents the mathematical ideas verbally, images and symbols (Paridjo \& Waluyo, 2017).

Research from Lomibao, et al. (2016) showed that the students exposed to mathematical communication approach have significantly higher achievement, conceptual understanding and significantly reduced anxiety compared to the Dynamic Learning Program (DLP) approach. So that mathematical communication is effective in improving students' achievement, conceptual understanding, and reducing anxiety. In other research, Pape et al. (2003) showed that students who are able to communicate their ideas have a better grasp of their own understanding. It is important for students to have good communication skills in the classroom because they then can use this skill to justify their work (Wichelt, 2009).

In the preliminary study, the result showed that elementary school students have not been able to communicate the mathematical concept well especially in the concept of geometry. There are some of difficulties when students were given one example of a three-dimensional geometric shapes object model. Students have difficulties to understand and communicate the basic concepts of three-dimensional geometric shapes consisted of explaining the characteristics of three-dimensional geometric shapes, drawing the three-dimensional geometric shapes, and making the the simple nets of three-dimensional geometric shapes. It shows the lack of mathematical communication skills of students in elementary school.

Moreover, the importance of developing mathematical communication skills is also based on the results of TIMSS (Trends in International Mathematics and Science Study) in 2015, which the target students in Indonesia are $4^{\text {th }}$ grade elementary students to measure the achievement of mathematics and science of elementary school students in international studies. The results obtained at TIMSS 2015 are Indonesia still in the order of 45 of the 50 participating countries in the TIMSS (Pusat Penilaian Pendidikan Badan Penelitian dan Pengembangan, 2017). This indicates that mathematics learning still needs improvement both in terms of quantity and quality of learning. Based on TIMSS results it is also found that Indonesian students have mastered routine question, simple computation, and measuring knowledge of daily contextual facts. However, Indonesian students still need to reinforce the ability to integrate information, draw conclusions, and generalize the knowledge they possess to other things (Rahmawati, 2016). The need for strengthening is one of them by training students to have the ability of mathematical communication.

Mathematical communication both orally and in writing in mathematics class can help deepen their conceptual understanding. By encouraging students to interact with others, they are able to construct individual understanding and concept formation (Lomibao, et al., 2016). Baroody (1993) stated that at least two reasons for mathematical communication should be the focus of attention are (1) thinking tools, tools for finding patterns, problem solving, tools for communicating ideas and (2) the means of communication between students and communication between teachers and students. Moreover, students with mathematical communication skills can comunicate clearly and coherently the mathematical ideas to other students as well as analyzing and evaluating the mathematical ideas of other students (Lim \& Chew, 2007).

On the other hand, the process of mathematics learning in elementary schools is still focused on the more active teachers in the classroom. Most of teachers only use the auditory learning style in the classroom where the student activity is just sitting and listening, while not all students can understand the learning easily by listening, it needs other activities that can support the student learning process. In this case, students have not been given the opportunity to perform other activities besides listening. Students are not much given the opportunity to gain direct experience in the learning process so that it causes low understanding of mathematical concepts and mathematical communication skill of students. Application of the learning model that emphasizes the development of students' mathematical communication skills such as reciprocal teaching approach can change the paradigm of learning, from the old paradigm where the 
teacher as a learning center into a new paradigm in which students become the center of learning, and teacher as a motivator and facilitator (Qohar, 2011).

Based on that explanation, it is necessary an approach that can improve students' mathematical communication skills. The SAVI approach (Somatic, Auditory, Visualization, Intellectually) is a learning approach that optimizes the function of human sensory devices included psychomotor, hearing, vision, and cognitive ability. According to research conducted by Utama, et al. (2014) The results show that there are significant differences in the results of learning mathematics between students who are taught through SAVIbased model of Open Ended with students who learned through conventional learning. By using SAVI approach, students can gain a direct experience of expressing mathematical concepts and ideas by optimizing their entire ability and senses. Mathematics learning will be better if students can active and involves their experience. As Dave Meier (2003, p. 91) states that learning does not automatically increase by making people stand and move around here. But combining physical movements with intellectual activity and the use of all senses can have a great impact on learning. In other words, the learner is not only present in the classroom, but the students also actively utilize all their modalities, which include somatic, auditory, visualization, and intellectually modality to construct their own understanding towards the learning materials they are learning (Santosa, 2012).

In addition, ethnomatematics are culture-based mathematical learning. Ethnomatematics by D'Ambrioso (Favilli, 2004) are the prefix "ethno" is today accepted as a very broad term that refers to the social-cultural context, and therefore includes language, jargon, and codes of behavior, myths, and symbols. The derivation of "mathema" is difficult, but tends to mean to explain, to know, to understand, and to do activities such as ciphering, measuring, classifying, ordering, inferring, and modeling. The suffix "tics" is derived from "techne", and has the same root as art and technique. The existence of culture is very close to the daily life of students. Each student has their own cultural background. Such as cultural diversity can be a source of learning in mathematics learning in elementary schools. Barta and Brenner (2009) stated ethnomathematics provides a way to better understand the reciprocal nature of mathematics and culture, of how culture influences the way cultural communities implement mathematical applications, skills, and knowledge in solution to problems encountered daily, and how these culturally inspired responses reciprocally affect the way mathematics is conceived and applied in each particular group.

In brief, the ethnomathematics-based SAVI approach is a mathematical learning approach that optimizes the function of human sensory functions and involves the cultural elements from the student environment. One of the ethnomatematics forms used in this study is cultural outcomes of buildings and historical relics related to the geometric model of space building in Banten Province, Indonesia. The ethnomatematics-based SAVI approach can facilitate students in understanding mathematical concepts and mathematical communication skills. Students can be faced with a more real situation that comes from the culture in their environment. So this research aim to : 1) obtain a description of the effect of ethnomathematics-based SAVI approach on mathematical communication skill of students in geometry in class V State Elementary School in Serang, Banten Province, Indonesia, 2) gain an overview of the results of mathematical communication skill of students using ethnomathematics-based SAVI approach better than using conventional learning.

\section{METHODOLOGY}

This research adopted quantitative research which is experimental research. In this research there are two research subjects that were experimental group and control group. Experimental group used the ethnomathematics-based SAVI approach, while the control group used conventional learning. Both experimental and control groups were also given tests which are pretest and posttest. The research employed quasi-experiment which is nonequivalent control group design. The first class became an experimental class given the treatment using the ethnomathematics-based SAVI approach and second class became a control class using conventional learning. The design of this research can be described as follows (Sugiyono, 2013):

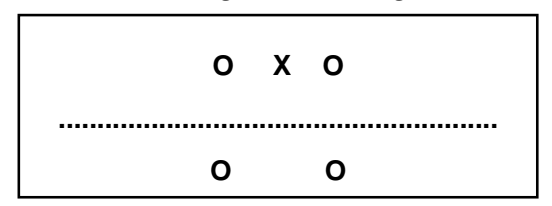

Fig. 1. The Research Design

Description :
$0=$ = Pretest and posttest of mathematical communication skill
$\mathbf{X}=$ Mathematics learning process using ethnomathematics-based SAVI
.... = Subject not selected randomly. 
This research was located at one of elementary school in Serang, Indonesia. The subjects of this research were 76 students of class A as an experimental class and class B as a control class, elementary school in Serang. The number of VA class was 38 students and of VB class were 38 students.

The instrument of this research are tests which are mathematical communication skill test consisted pretest and posttest and interview. Pretest is the first test aimed to determine the students' mathematical communication skill before obtaining ethnomathematics-based SAVI learning in experimental class and conventional learning in control class. The posttest is the final test aimed to determine the students' mathematical communication skills after they were given ethnomathematics-based SAVI learning in the experimental class and conventional learning in the control class. The test of mathematical communication skills used was an essay test aimed to determine the students' ability to express mathematical ideas through the way students complete the test. Moreover, the errors and difficulties experienced by the students can be known so that teacher can improve the learning process. The indicators of mathematical communication skill used based on the NCTM (2000), the indicators in this test are: 1) Reflecting on real objects, drawings and diagrams into math ideas; 2) Describing ideas, situations, and math relationships verbally or in writing with real objects, images, and algebra.

The development of test instruments in this research consisted of validity and reliability. Based on the instrument development that has been done, the overall validity of the results indicates that the question is good. While the validity of the overall contents of the question was good, it was appropriate with the indicator, and according to the contents of the material to be tested. The reliability test has been analyzed through Anates software, it is found that the reliability level is 0.49 which means it has a moderate level of reliability. Furthermore, the data of students' mathematical communication skill were analyzed to determine whether the data were distributed normally, homogeneous, and there was an average equality in the data of both samples. Moreover, the data were analyzed the value of the early ability test (pretest) with the final ability test (posttest) through N-Gain analysis. For test and analyze the data, it used SPSS version 21 for windows and Microsoft Excel.

The interview instrument focused on to know deeply how students feel in learning process using an ethnomatematics-based SAVI approach. Interviews were conducted on several student representatives from each of the low, medium, and high groups. Interviews were conducted after the students obtained treatment through the learning process with the ethnomathematics-based SAVI approach. The result of interview was analyzed by qualitative.

\section{RESULT AND DISCUSSION}

\subsection{Result}

The research was begun by doing pretest on experimental class and control class. Pretest was given to students of experimental class and control class before they were given the learning process aimed at understanding the early mathematical communication skills of the students. After the early student ability was identified by pretest in both classes, treatment was performed with different treatment in experimental class and control class. The experimental class was given the treatment using ethnomathematics-based SAVI approach, and the control class was given learning using conventional approach. After that, both samples were given a final test or posttest aimed to determine the final ability of students in working on the mathematical communication of students.

The result of descriptive statistics data showed that the pretest average of students' mathematical communication skill is 40.92 in experimental class and 34.74 in control class. While the posttest average of students' mathematical communication skill is 72.11 in experimental class and 60.53 control class. Then the data were tested for normality test, homogeneity test, and t test to determine whether there is a difference between the score of pretest and posttest in experimental class and control class or not. The analysis of pretest of students' mathematical communication skill below:

Table 1. Normality test of Pretest Data

\begin{tabular}{|c|c|c|c|c|c|}
\hline \multirow{2}{*}{ Class } & \multicolumn{3}{|c|}{ Shapiro-Wilk } & \multirow{2}{*}{ Conclusion } & Meaning \\
\cline { 2 - 4 } & Statistic & $\mathrm{df}$ & Sig. & & \\
\hline Experiment & 0.963 & 38 & 0.234 & $\mathrm{H}_{0}$ Accepted & Normal Distribution \\
\hline Control & 0.976 & 38 & 0.568 & $\mathrm{H}_{0}$ Accepted & Normal Distribution \\
\hline
\end{tabular}


Based on table 1, the result of normality test from 38 students of the experimental class obtained the significance value of 0.963 and from 38 students of control class obtained the significance of 0.976 . The value of both is more than the significance level $(>0.05)$, which means both classes have been distributed normally and $\mathrm{H}_{0}$ is acceptable. It can be summarized the data of pretest are normal both in experimental class and control class. The homogeneity test was analyzed by using SPSS and it obtained the significance 0.562 which means the data of pretest is homogenous. Furthermore, the result of $t$-test below:

Table 2. t-test of Pretest Data

\begin{tabular}{|c|c|c|c|c|}
\hline & $\mathrm{t}$ & $\mathrm{df}$ & Sig. (2-tailed) & Conclusion \\
\hline $\begin{array}{c}\text { Equal variances } \\
\text { assumed }\end{array}$ & 1.685 & 74 & 0.096 & $\mathrm{H}_{0}$ Accepted \\
\hline
\end{tabular}

Based on the table 2, it is obtained value of significance is 0.096 which is more than 0.05 , so that $\mathrm{H}_{0}$ is accepted. This showed that the student achievement value in pretest of mathematical communication skills has the same average value between experimental class and control class. The result of posttest data analysis or final ability test shown below:

Table 3. Normality test of Posttest Data

\begin{tabular}{|c|c|c|c|c|c|}
\hline \multirow{2}{*}{ Class } & \multicolumn{3}{|c|}{ Shapiro-Wilk } & \multirow{2}{*}{ Conclusion } & \multirow{2}{*}{ Meaning } \\
\cline { 2 - 4 } & Statistic & Df & Sig. & & \\
\hline Experiment & 0.954 & 38 & 0.117 & $\mathrm{H}_{0}$ Accepted & Normal Distribution \\
\hline Control & 0.956 & 38 & 0.145 & $\mathrm{H}_{0}$ Accepted & Normal Distribution \\
\hline
\end{tabular}

Based on table 3 , the result of posttest data analysis or final ability test showed that the posttest of both classes has normal distribution. From 38 students of the experimental class obtained the significance value of 0.117 and from 38 students of control class obtained the significance of 0.145 . The value of both is more than the significance level $(>0.05)$, which means that if looking at decision-making criteria, Shapiro-Wilk data generated from both classes has been distributed normally and $\mathrm{H}_{0}$ is acceptable.

The experimental class homogeneity test has a significance value of 0.789 . The significance value is more than 0.05 . So according to criteria of decision making the data of posttest included homogeneous. On the average equation test ( $t$ test) was known hypothesis $\left(\mathrm{H}_{0}\right)$ which means there is a similarity of average value of the final ability test of the experimental class and the control class and the hypothesis $\left(H_{1}\right)$ which means that there is no similarity of average value of the final ability test of the experimental class and control class.

Table 4. t-test of Posttest Data

\begin{tabular}{|c|c|c|c|c|}
\hline & $\mathrm{t}$ & $\mathrm{df}$ & Sig. (2-tailed) & Conclusion \\
\hline $\begin{array}{c}\text { Equal variances } \\
\text { assumed }\end{array}$ & 3.148 & 74 & 0.002 & $\mathrm{H}_{0}$ Rejected \\
\hline
\end{tabular}

Based on decision making criteria, if (sig.) $<0.05$, so $\mathrm{H}_{0}$ is rejected. The average similarity test results has been obtained with a significance value of less than 0.05 that is 0.002 which means that the student's achievement value in the final ability test of student's mathematical communication skills does not have the similarity of average values between experimental class and control class.

Moreover, at the data analysis stage, the N-Gain data analysis was aimed to find out the extent to which students' mathematical communication skills increased during the study, viewed from pretest results to posttest between experimental class and control class. In this case, N-Gain was calculated using the Microsoft Excel program, the calculation was done by dividing the pretest score and posttest with the difference in ideal score and pretest score.

Based on the data processing of the N-Gain enhancement of experimental and control class students, it obtained the lowest value, highest value, average value, variance, and N-Gain deviation standard from the experimental class and the control class. The data was obtained by using SPSS software program version 21.0 for windows by using descriptive analysis and obtained the data below: 
Table 5. Descriptive N-Gain

\begin{tabular}{|c|c|c|c|c|c|c|}
\hline \multicolumn{8}{|c|}{ Descriptive Statistic N-Gain } \\
Class & $\mathrm{N}$ & Min & Max & Mean & Std. Deviation & Variance \\
\hline Experiment & 38 & 0.00 & 1.00 & 0.53 & 0.2683 & 0.07 \\
\hline Control & 38 & 0.00 & 0.75 & 0.38 & 0.2125 & 0.05 \\
\hline
\end{tabular}

Based on the data in table 5 , it can be seen that the results of experimental class has increased with an average of 0.53 while in the control class has increased by an average of 0.38 . Based on the N-Gain criteria, the average quality of the experimental study result of 0.53 is medium $(0.3<\mathrm{g} \leq 0,7)$ and the average improvement in the learning grade of 0.38 is also medium. But in this case it can be seen that the increase in experimental class is more than the control class.

Furthermore, the N-gain data was tested by normality and homogeneity test. Based on the normality test, both N-Gain data of experimental and control class is normal with signifinicance 0.39 in experimental class and 0.24 in control class. From the homogeneity test, it obtained the significance is 0.277 which means that the data of posttest is homogenous. The t-test data aimed to to test the difference in the average N-Gain of mathematical communication skills with the following hypotheses are $\mathrm{H}_{0}$ that if there is no average difference between $\mathrm{N}$-Gain students' mathematical communication skills between experimental class and control class and $\mathrm{H}_{1}$ that if the $\mathrm{N}$-Gain average of students' mathematical communication skills in experimental class is better than in control class. Based on the analysis using SPSS, the data obtained below:

Table 6. t-test of N-Gain

\begin{tabular}{|c|c|c|c|}
\hline & $\mathrm{t}$ & $\mathrm{df}$ & Sig. (2-tailed) \\
\hline $\begin{array}{c}\text { Equal variances } \\
\text { assumed }\end{array}$ & 2.683 & 74 & 0.009 \\
\hline
\end{tabular}

Based on the table 6, it was obtained that the significance is 0.009 divided two, so that the result was 0.045 which is less than the significance rates $(0.05)$, so that $H_{0}$ is rejected. The result of $t$ test showed that students' mathematical communication skill using ethnomathematics-based SAVI approach is better than students' mathematical communication skill using conventional approach.

The interview was conducted after treatment and the final test of the experimental class was completed. Based on the results of the interview, it was generally found that the learning with the ethnomatematicsbased SAVI approach was very happy and became more interested in learning mathematics. Students were also delighted with the images of historic buildings shaped such as Banten tower and Banten mosque. While practicing discovering characteristics and nets of three-dimensional geometric shapes through student work sheet. Students were also enthusiastic and very interested. Here are one of the student results of mathematical communication skill test:

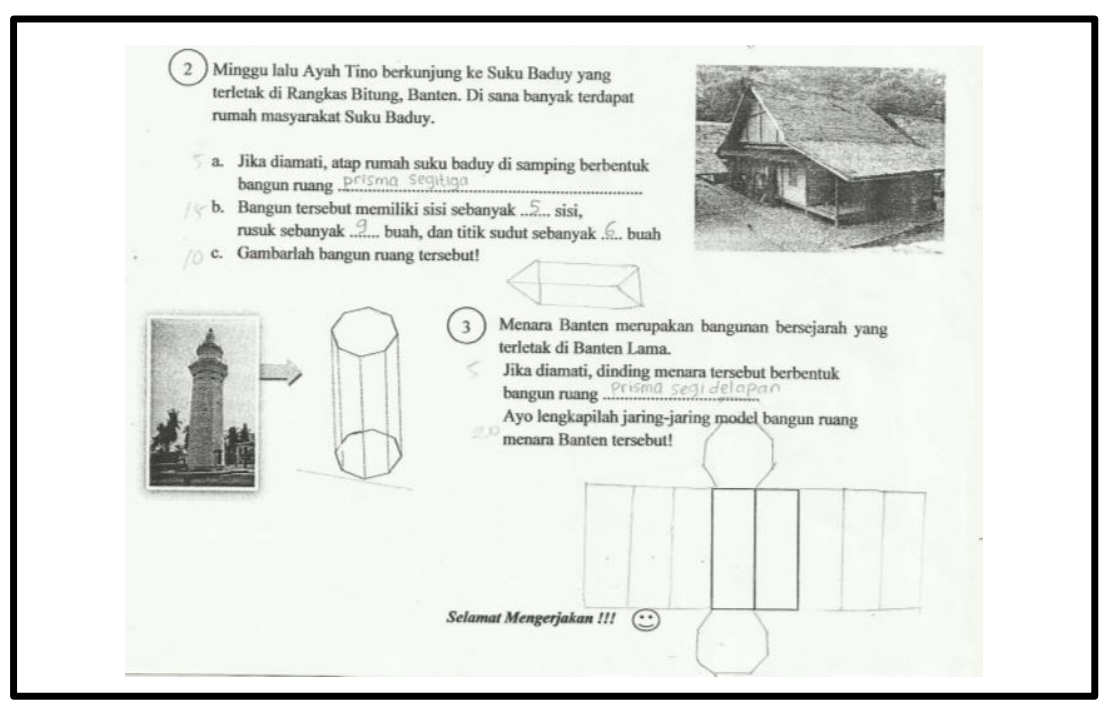

Fig. 2. Students Result of Mathematical communication skill test 
Based on Fig.2, the mathematical communication of student can be seen from question number 2:

Last week Tino's Father goes to Baduy tribes located in Rangkas Bitung, Banten, Indonesia. He look there are many Baduy's homes.

a) Please observed, the form of three-dimensional geometric shapes of Baduy's House is........

b) That three-dimensional geometric shapes object model have ....... sides

c) Draw that three-dimensional geometric shapes object model!

Student answer by writing and drawing appropriately. Student write "triangular prism" and it have " 5 sides". Then student draw the triangular prism resemble the roof of Baduy's house. That student answer is correct. Student can communicate their idea by writing in the worksheet. Moreover, the mathematical communication of student also can be seen from question number 3 :

The Banten tower is a historical building located in Banten Lama. Please observed, the form of the wall of tower is........... Complete the nets of the form of three-dimensional geometric shapes of Banten Tower!

Student can aswer the question by writing and drawing the nets of three-dimensional geometric shapes.Based on the result, it is showed that student can communicate well in mathematical concept. Students can image and the communicate in writing the mathematical ideas. Students can identity the characteristics and draw the nets of three-dimensional geometric shapes. After studying using the ethnomatematics-based SAVI approach, students became more understood with the geometry concept such as the pyramid and prism, the concept is easy to remember since previous students could practice finding the nets. The disadvantages the students are only disturbed by the noisy mood of working in groups. In addition, there is no significant lack of learning that has been implemented. It can be concluded that learning using this ethnomathematics-based SAVI approach has been successfully implemented as it has a positive impact on mathematical learning process.

\subsection{Discussion}

This research was conducted to obtain a description of the effect of ethnomathematics-based SAVI approach on mathematical communication skill of students in geometry in $5^{\text {th }}$ grade one of elementary school in Serang, Indonesia. After the experimental and control class were given the mathematical learning process with a different approach. They were given the posttest. The data were analyzed by using SPSS, it found that the data were normal and homogenous, the t-test was conducted to test the significance of the results of the study in the form of a comparison of the state of the variable of the two meanings between the experimental class and the control class, whether there was a similar initial ability of the students from both classes.

According to the average equation test ( $t$ test), the average similarity test results had been obtained with a significance value of less than 0.05 that is 0.002 which meant that the student's achievement value in the final ability test of student's mathematical communication skills did not have the similarity of average values between experimental class and control class. The results can be described as follows:

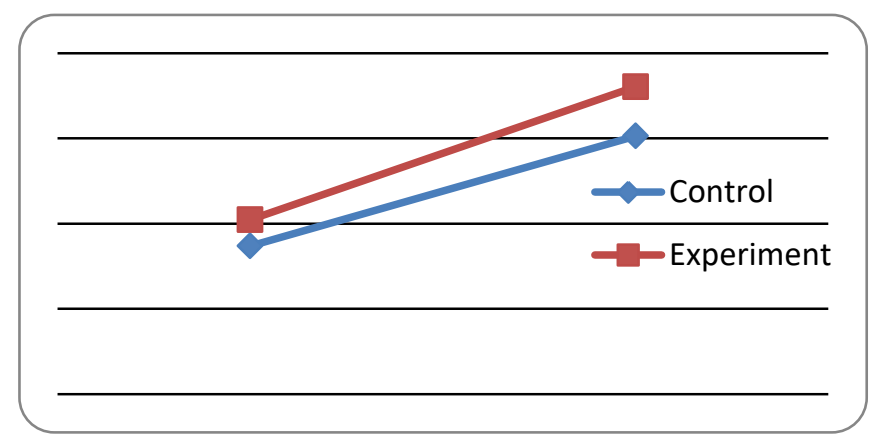

Fig. 3. The Students' mathematical communication skill

In the graph above we could also see based on the treatment, the experimental class got the most value compared to the acquisition of values in the control class especially on average pretest and posttest. At the posttest of mathematical communication skills, the experimental class got an average of 72.11 , while the control class got an average of 60.53 . There was a difference of 11.58. In addition, the average increase in the mathematical communication skills of experimental classes was also greater than the control class. This meant that learning with ethnomathematics-based SAVI affected the ability of mathematical communication. 
The effect of mathematical communication skill of this experimental class is due to the fact that the class was treated differently with the usual approach of the ethnomathematics-based SAVI, students were given learning that was able to provide students with immediate experience through their own sensory function. Students did not directly took lessons or materials from the teacher but try to find and practice them so that learning became more understandable and of course interesting for students. It is as Dave Meier's theory stated that:

Learning can be optimal if the four SAVI elements are in one learning event. For example, people can learn a bit by watching the presentation $(\mathrm{V})$, but they can learn much more if they can do something while the presentation is in progress (S), talk about what they are learning (A), and think about how to apply the information in the presentation in their work (I). Or they can improve their ability to solve problems (I) if they simultaneously move something $(\mathrm{S})$ to produce a three-dimensional pictogram or display $(\mathrm{V})$ while talking about what they are doing (A) (Dave Meier, 2003, p.100).

Secondly, this research was conducted gain an overview of the results of mathematical communication skill of students using ethnomathematics-based SAVI approach better than using conventional learning. Based on the results of the research, it had been shown that students' mathematical communication skills in experimental class using the ethnomathematics-based SAVI approach were better than those in the control class using conventional approach. This could be seen from the acquisition of student values in the posttest that show the average difference in the value between the experiment class and the control class.

After experimental class were performed differently in with control class, where experimental class were given the treatment of ethnomatematics-based SAVI while the control class was treated with conventional approach, the average result of posttest was 72.11 in the experimental class and 60.53 in the control class . This indicates that there was an increase in the average value of both classes, but the increase in the experimental class is higher. It is also proved by the average similarity test of both classes by using SPSS 21 for windows which showed the result of significance of 0.002 which was included under the significant level so that there was no meaning of average similarity in both classes.

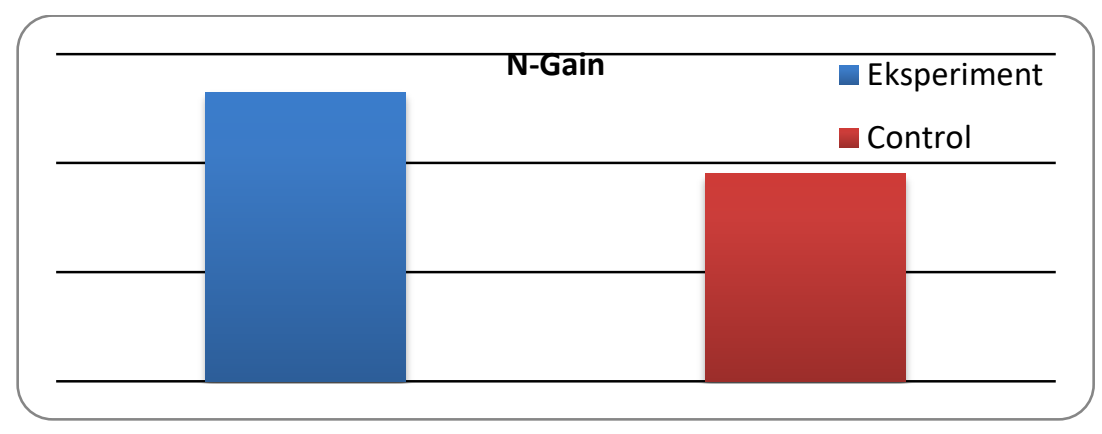

Fig. 4. The N-Gain test results

The improvement of mathematical communication skills could also be seen in N-Gain test results. Based on the results of the $\mathrm{N}$-Gain test that had been done, the results of experimental class had increased with an average of 0.53 while in the control class increased by an average of 0.38 . The result of $t$ test showed that the significance result was 0.045 which was less than the significance rates (0.05), so that students' mathematical communication skill using ethnomathematics-based SAVI approach is better than students' mathematical communication skill using conventional approach.

In the early activities of teacher learning trying to create a positive learning environment then teachers motivated students to be more excited in learning. The teacher then provided apperception to explore the prior knowledge of the students. Afterwards the teacher displayed a visual display of cultural images as a visual activity of the students. Teachers with students asked questions about the model of the classroom setting up by the teacher.

In the learning process, the teacher tries to present a learning process that is able to encourage somatic, auditory, visualization, and intellectually activities for students. At this stage, the teacher and students have begun to start the core activities of the learning process. The teacher showed cultural images such as Banten Tower building and Banten Grand Mosque. Teacher showed a model of three-dimensional geometric shape object as a miniature of Banten Tower and Banten Mosque made of cardboard. Teachers motivated students to observe (visual activity) and asked questions about objects that the teacher showed. As in core activities, students are encouraged to work in groups. Students work on student worksheet by performing somatic, auditory, visualization, and intellectually in the group. Each group was given student worksheet and tools of media. From the form of tools of media the students are directed to create a model in the form of 
pictures three-dimensional geometric shapes in writing. In this activity students attempt to construct knowledge into themselves through the four SAVI activities within the group. In this case, the teacher acts as facilitator who guides and motivates students to solve problems in the student worksheet with the ideas of each group member.

After students work in groups, the teacher directs students to present their work in front of the class. This activity is part of the auditory activities that are part of the student's ability to improve the mathematical communication skills verbally. This is shown by previous research which has the conclusion that students' mathematical communication in verbal and writing through SAVI (Somatic, Auditory, Visualization, Intellectually) approach is in a good category which showed that students can do mathematical communication activities included in writing mathematical ideas, mathematical representation of the material, the important points of the material, the problem into the mathematical model, the mathematical problems, and a summary related the material that has been learned well (Maghfiroh, et.all, 2017).

\section{CONCLUSION}

In summary, learning by using the ethnomathematics-based SAVI approach in the experimental class has improved mathematical communication skills. This is evidenced by the experimental class $\mathrm{N}$-Gain value obtained in the experimental class including the medium gain category. Based on that, it means that mathematics learning using ethnomathematics-based SAVI approach affects the mathematical communication skills of State Elementary School Serang 11 students. Furthermore, Experimental students who get learning using ethnomathematics-based SAVI approach have improved the ability of mathematical communication higher than the control class students who get learning with conventional approach. This is evident from the average posttest of experimental class that is higher than the average control class. On the other hand, the enhancement of the $\mathrm{N}$-Gain of both classes included in the medium classification. If viewed from the average N-Gain value also shows the experimental class is higher than the control class. The result of t test showed that students' mathematical communication skill in experimental class is better than students' mathematical communication skill in control class. Therefore, it can be concluded that the mathematical communication ability of the students in the experimental class with learning using the ethnomathematics-based SAVI approach is better than the control class students who get learning using conventional approach. For the next research, researcher can continue or explore this topic to give improvement for mathematics learning in elementary school.

\section{ACKNOWLEDGEMENT}

The authors would like to express thanks and the appreciation to LPDP (Lembaga Pengelola Dana Pendidikan) from Ministry of Finance of the Republic of Indonesia for providing financial support both for the magister study in Magister Program of Universitas Pendidikan Indonesia and also for the opportunity to attend this conference and to publish this paper.

\section{REFERENCE LIST}

Baroody, A., J. (1993). Problem Solving, Reasoning, and Communicating (K-8). New York: Macmillan Publishing Company.

Barta, J., \& Brenner. M. E. (2009). Seeing With Many Eyes: Connections between Anthropology and Mathematics. Published in Culturally Responsive Mathematics Education book. New York: Routledge

Favilli, F. (2004). Etnomathematics and Mathematics Education. Proceedings of the 10th International Congress of Mathematics Education Copenhagen

Kemendikbud. (2016). Silabus Mata Pelajaran Sekolah Dasar/Madrasah Ibtidaiyah (SD/MI). Jakarta: Kemendikbud.

Lim, C.S., \& Chew, C. M. (2007). Mathematical Communication in Malaysian Bilingual Classrooms. Japan: the 3rd APEC-Tsukuba International Conference: Innovation of classroom teaching and learning through lesson study- focusing on mathematical communication.

Lomibao, L. S, Luna, C. A, \& Namoco, R. A. (2016). The Influence of Mathematical Communication on Students' Mathematics Performance and Anxiety. American Journal of Educational Research, 2016, Vol. 4, No. 5, 378-382.

Maghfiroh, M., Baiduri., \& Ummah, S.K. (2017). Analysis of Students' Mathematical Communication of Junior 
High School (Smp) Through The SAVI (Somatic, Auditory, Visualization, Intellectually) Approach. Mathematics Education Journals, 1 (2).

Meier, D. (2003). The Accelerated Learning Handbook. Bandung: Kaifa.

NCTM. (2000). Principles and Standards for School Mathematics. USA: NCTM.

Ollerton, M. (2010). Panduan Guru Mengajar Matematika. Jakarta: Erlangga.

Pape, S. J., Bell, C. V., \& Yetkin, I. E. (2003). Developing Mathematical Thinking and Self-Regulated Learning: A Teaching Experiment in a Seventh-Grade Mathematics Classroom. Education Studies in Mathematics, Vol. 53, 179-202.

Paridjo., \& Waluya. S. B. (2017). Analysis Mathematical Communication Skills Students In The Matter Algebra Based Nctm. IOSR Journal of Mathematics (IOSR-JM), 13 (I).

Partnership for $21^{\text {st }}$ century learning. (2007). Framework for $21^{\text {st }}$ century learning. Washington DC.

Pusat Penilaian Pendidikan Badan Penelitian dan Pengembangan. (2017). Hasil TIMSS 2015. Accessed in http://www.acdp-indonesia.org/wp-content/uploads/2017/01/TIMSS-infographic.pdf [13 April 2017].

Rahmawati. (2016). Hasil TIMSS 2015. Accessed in [13 April 2017]

Qohar, A. (2011). Mathematical Communication: What And How To Develop it in Mathematics Learning? Proceeding International Seminar and the Fourth National Conference on Mathematics Education.

Santosa, E. B. (2012). Somatic Auditory Visual Intellectual (Savi) Approach in Character Education in Higher Education. Proceeding Instructional strategy and ICT for Higher Education.

Sugiyono. (2013). Metode Penelitian Pendidikan. Bandung: Alfabeta.

Utama, W. A, Suniasih, N. W, \& Putra, K. N. S. (2014). Pengaruh Model Pembelajaran SAVI Berbasis Open Ended Terhadap Hasil Belajar Matematika Pada Siswa Kelas V SD Gugus III Sukawati.

Wichelt, L. (2009). Communication: A Vital Skill of Mathematics. University of Nebraska - Lincoln. 